\title{
PENGARUH STRATEGI PEMBELAJARAN DAN MINAT MENJADI GURU TERHADAP HASIL BELAJAR MATA KULIAH PERENCANAAN PEMBELAJARAN BIOLOGI: Studi Eksperimen Pada Jurusan Pendidikan IPA Biologi IAIN Mataram
}

\author{
Yusuf \\ Dosen Pendidikan IPA Biologi FITK IAIN Mataram
}

\begin{abstract}
Abstrak
Penelitian eksperimen ini untuk mengetahui pengaruh strategi pembelajaran dan minat menjadi guru terhadap hasil belajar mata kuliah perencanaan pembelajaran biologi. Perlakukan stategi pembelajaran, yaitu strategi kontekstual sebagai perlakuan dan strategi konvensional sebagai pembanding pada kelompok mahasiswa memiliki minat tinggi menjadi guru dan kelompok mahasiswa memiliki minat rendah menjadi guru. Sampel diambil dengan teknik Multistage Random Sampling dari populasi mahasiswa Jurusan Pendidikan IPA Biologi Semester VI tahun pelajaran 2013/2014 sebagai perlakuan pada rancangan Treatment by Level. Data minat menjadi guru dikumpulkan dengan angket dan hasil belajar mahasiswa dengan teknik tes. Data hasil tes dianalisis dengan ANAVA dua jalur pada taraf nyata 5\%. Hasil penelitian (1) untuk strategi pembelajaran: nilai probabilitas uji 0.020 lebih kecil dari alpha, 0.05, tolak HO, kesimpulannya, terdapat perbedaan hasil belajar mata kuliah Perencanaan Pembelajaran Biologi antara mahasiswa yang diajar dengan strategi pembelajaran kontekstual dan mahasiswa yang diajar dengan strategi konvensional, dan (2) Pengaruh interaksi strategi pembelajaran dan minat menjadi guru; nilai probabilitas uji = 0.004 lebih kecil dari alpha, 0.05, HO ditolak, kesimpulannya, terdapat pengaruh strategi pembelajaran dan minat menjadi guru terhadap hasil belajar mata kuliah Perencanaan Pembelajaran Biologi mahasiswa Jurusan Pendidikan IPA Biologi Fakultas Ilmu Tarbiyah Institut Agama Islam Negeri Mataram.
\end{abstract}

Kata Kunci: Kontekstual, minat menjadi guru, konvensional 


\section{PENDAHULUAN}

Fakultas Ilmu Tarbiyah dan Keguruan Institut Agama Islam Negeri (IAIN) Mataram sebagai salah satu lembaga pengembangan tenaga kependidikan memiliki beban akademik untuk membentuk tenaga profesional dalam bidang pendidikan. Profil lulusan Fakultas Ilmu Tarbiyah dan Keguruan IAIN Mataram yang sekaligus menjadi tujuan penyelenggaraan pendidikan adalah:

a. Menyiapkan peserta didik menjadi anggota masyarakat yang memiliki kemampuan akademik dan/atau profesional yang beriman dan bertaqwa (berakhlak mulia) serta dapat merumuskan, menerapkan, dan mengembangkan ilmu pengetahuan keislaman dan teknologi, khususnya dalam lingkup ilmu Pendidikan Islam (islamic education studies) yang berlandaskan ajaran Islam

b. Mengembangkan dan menyebarluaskan ilmu pengetahuan keislaman, teknologi dan seni, khususnya dalam lingkup ilmu Pendidikan Islam (islamic education studies) yang berlandaskan ajaran Islam, serta mengupayakan penggunaannya untuk meningkatkan pemberdayaan potensi serta taraf kehidupan masyarakat dan memperkaya kebudayaan nasional.

Berdasarkan tujuan tersebut, ada dua hal penting yang terlihat yaitu, pertama bahwa profil lulusan strata satu yang diamanatkan pada Fakultas Ilmu Tarbiyah dan Keguruan IAIN Mataram secara umum mengarah pada empat kompetensi guru yang diharapkan sebagaimana yang tertuang dalam Pasal 10 Undang-Undang Nomor 14 Tahun 2005 tentang guru dan dosen, yaitu kompetensi pedagogik, kompetensi kepribadian, kompetensi sosial, dan kompetensi profesional. Kedua adalah, bahwa kompetensi tersebut harus berdiri di atas pondasi ajaran islam yang menjadi ciri khasnya sebagai LPTK Islam. Jadi, apapun disiplin keilmuan yang dikembangkan dalam Fakultas Ilmu Tarbiyah dan Keguruan IAIN Mataram, termasuk Jurusan Pendidikan IPA Biologi menguasai dua domain kompetensi dan berdiri di atas pondasi tersebut. 
Demikian halnya dengan Jurusan Pendidikan IPA Biologi sebagai disiplin keilmuan profesional pada Fakultas Ilmu Tarbiyah dan Keguruan IAIN Mataram. Profil lulusan Jurusan Pendidikan IPA Biologi yaitu; pertama, memiliki kemampuan akademik dan/atau profesional yang beriman dan bertaqwa (berakhlak mulia) serta dapat merumuskan, menerapkan, dan mengembangkan IPA Biologi, dan kedua, mengembangkan dan menyebarluaskan IPA Biologi yang berlandaskan ajaran Islam, serta mengupayakan penggunaannya untuk meningkatkan pemberdayaan potensi serta taraf kehidupan masyarakat dan memperkaya kebudayaan nasional.

Sebagai upaya mewujudkan profil lulusan kurikulum sebagai software menjadi sangat penting kedudukannya dalam proses penyelenggaraan pendidikan dan pengajaran pada Jurusan Pendidikan IPA Biologi Fakultas Ilmu Tarbiyah dan Keguruan. Hasil analisis peneliti terhadap struktur kurikulum Jurusan Pendidikan IPA Biologi menunjukkan bahwa konten kurikulumnya terdiri dari tiga komponen, yaitu; pendidikan Islam, pendidikan dan pembelajaran, dan IPA khususnya biologi. Komponen yang terbesar porsinya adalah ilmu biologi, yaitu $40 \%$ dari komponen yang lain. Hal ini memungkinkan lulusan memiliki komptensi porfesional yang memadai dalam rangka mengembangkan dan menyebarluaskan IPA Biologi bagi peserta didik ketika menjadi guru.

Secara konten kurikulum sebenarnya sudah cukup memadai pengalaman belajar mahasiswa untuk memiliki komptensi pedagogic dalam merencanakan dan menyelenggarakan pembelajaran biologi di sekolah/madrasah. Tetapi, hasil analisis peneliti terhadap komponen silabus dan satuan acara perkuliahan (SAP) mata kuliah tersebut khususnya mata kuliah Perencanaan Pembelajaran Biologi menunjukkan bahwa pembelajaran masih terfokus pada penguasaan konsep tentang perencanaan, model-model pengembangan sistem instruksioanl, dan konsep pengembangan indikator, silabus, dan rencana pelaksanaan pembelajaran (RPP). Perkuliahan dilakukan dengan cara memberikan tugas kepada mahasiswa secara berkelompok untuk mendiskusikan topik perencanaan, model- 
model pengembangan sistem instruksioanl, dan konsep pengembangan indikator, silabus, dan rencana pelaksanaan pembelajaran (RPP). Setelah mahasiswa berdiskusi, setiap kelompok diberi kesempatan untuk pemempresentasikan hasil diskusi, kemudian selesai presentasi, dilakukan tanya jawab dengan anggota kelompok lain. Di akhir perkuliahan dosen memberikan penguatan atau menjelaskan hal-hal penting tentang materi yang didiskusikan. Dosen juga memberikan tugas secara individu untuk dikerjakan di luar jam kuliah. Tugas tersebut diberikan dengan tujuan untuk memperkuat pemahaman mahasiswa dan memberi latihan tambahan dalam rangka penerapan konsep, misalnya, mengembangkan indikator, menyusun silabus, dan menyusun rencana pelaksanaan pembelajaran (RPP).

Pembelajaran mata kuliah Perencanaan Pembelajaran Biologi sebagaimana yang dipaparkan di atas membawa masalah tersendiri terhadap hasil belajar mahasiswa, terutama yang berkaitan dengan kemampuan mahasiswa dalam melakukan praktik perencanaan pembelajaran biologi sesuai kurikulum. Salah satu bentuk nyata yang dapat dilihat adalah kemampuan mahasiswa merumuskan komponen kegiatan pembelajaran pada silabus dan Rencana Pelakasanaan Pembelajaran (RPP). Hasil penelitian awal yang dilakukan oleh peneliti terhadap dokumen RPP yang dikembangkan oleh mahasiswa Jurusan Pendidikan IPA Biologi pada saat persiapan dan simulasi mengajar mata kuliah Microteaching semester ganjil tahun akademik 2012/2013 dan RPP yang dikembangkan mahasiwa ketika palaksanaan Praktik Pengalaman Lapangan (PPL) semester genap tahun akademik 2012/2013 diperoleh gambaran kelemahan sebagai berikut:

- Perumusan indikator dan tujuan pembelajaran yang kurang sesuai dengan kompetensi dasar (KD) pada standar isi (SI) mata pelajaran biologi di sekolah/madrasah.

- Belum logisnya antara tujuan pembelajaran dengan; kegiatan pembelajaran yang dipilih, materi pokok, media yang digunakan, dan tes yang rencanakan. 
- Pemilihan model pembelajaran atau metode pembelajaran yang kurang tepat dengan indikator/tujuan pembelajaran.

- Tidak sesuai antara model pembelajaran atau metode pembelajaran yang dipilih dengan langkah/kegiatan pembelajaran yang dilakukan pada kegiatan awal, kegiatan inti, dan kegiatan penutup.

- Kurang detailnya tahapan langkah pembelajan yang akan dilakukan guru sebagai implementasi model pembelajaran atau metode pembelajaran yang dipilih. Hal ini menggambarkan ketidakpahaman mahasiswa secara utuh terhadap penerapan konsep strategi pembelajaran.

- Ketidakpatuhan pemilihan model pembelajaran atau metode pembelajaran yang dipilih dengan sumber belajar yang diperlukan dalam proses pembelajaran seperti perlunya Lembar Kerja Siswa (LKS) dan media pembelajaran.

Salah satu permasalahnya adalah kegiatan perencanaan pembelajaran yang hanya terfokus komptensi dasar (KD) yang terdapat pada standar isi kurikulum. Mahasiswa hanya dibiasakan untuk mengembangkan indikator, menyusun tujuan pembelajaran, merumuskan strategi pembelajaran, menentukan media pembelajaran, dan merumuskan cara penilaian dengan cukup menganalisis Standar Kompetensi dan Kompetensi Dasar pada Standar Isi Kurikulum. Pembelajaran mestinya juga harus menghadirkan atau dihadapkan pada objek nyata secara kontekstual, misalnya ketika mahasiswa membuat perencanaan pembelajaran biologi untuk materi ekosistem atau KD tentang ekosistem, mahasiswa harus dihadapkan pada ekosistem yang nyata sambil menelaah SK dan KD di tempat itu.

Persoalan tidak melibatkan objek biologi secara kontekstual pada aktivitas perencanaan pembelajaran biologi dan kurang praktisnya pembahasan mengenai perencanaan pembelajaran yang ada pada literatur bukanlah penyebab tunggal yang mengakibatkan rendahnya hasil belajar mahasiswa terutama kemampuan mahasiswa melakukan kegiatan perencanaan pembelajaran biologi untuk sekolah/madrasah. Persoalan lain 
yang mempengaruhi hasil belajar mahasiswa pada LPTK adalah minat mahasiswa menjadi guru. Minat seorang mahasiswa menjadi guru sangat penting, karena salah satu prinsip profesi guru yang disebutkan dalam Undang-Undang Republik Indonesia Nomor 14 tahun 2005 tentang Guru dan dosen pasal 7 mengamanatkan bahwa, Profesi guru dan profesi dosen merupakan bidang pekerjaan khusus yang dilaksanakan berdasarkan prinsip memiliki bakat, minat, panggilan jiwa, dan idealisme. Halimah Harun menyatakan bahwa proses pendidikan dan latihan guru haruslah menentukan calon guru mempunyai minat, sikap, dan motivasi yang tinggi terhadap profesinya sebagai guru serta memiliki keterampilan yang tinggi dalam aspek pengajaran dan pembelajaran .

Permasalahan yang terjadi pada mahasiswa Jurusan Pendidikan IPA Biologi IAIN Mataram adalah bervariasinya intensitas minat minat mereka menjadi guru. Hal ini terungkap dari hasil observasi awal peneliti melalui wawancara dengan 12 orang mahasiswa mengenai pengetahuan mereka tentang profesi guru, aktivitas yang mereka lakukan dalam mendukung profesi guru, dan pekerjaan yang akan mereka lakukan setelah tamat S1 Pendidikan pada Fakultas Ilmu Tarbiyah dan Keguruan IAIN Mataram. Hasil observasi menunjukkan, bahwa (1) hanya 5 dari 12 orang $(41,67 \%)$ yang dapat menjawab pertanyaan sederhana mengenai kompetensi guru, (2) mahasiswa yang memiliki buku/membaca buku-buku seperti perencanaan pembelajaran dan strategi pembelajaran adalah 8 dari 12 orang (66,67\%), dan (3) terdapat $66,67 \%$ juga mahasiswa yang konsisten akan menjadi guru setelah wisuda dan 33,33\% menyatakan tidak tahu dan bekerja pada sektor yang lain, seperti bisnis. Fakta ini menandakan bahwa tidak semua mahasiswa Jurusan Pendidikan IPA Biologi memiliki minat yang tinggi menjadi guru di sekolah/madrasah. Oleh sebab itu, peneliti dilakukan dalam rangka mengetahui pengaruh strategi pembelajaran dan minat menjadi guru terhadap hasil belajar mata kuliah Strategi Pembelajaran Biologi pada mahasiswa jurusan Pendidikan IPA Biologi. Tujuan penelitian adalah untuk mengetahui; (1) perbedaan hasil belajar mata kuliah Perencanaan Pembelajaran Biologi antara mahasiswa yang diajar 
dengan strategi pembelajaran kontekstual dan mahasiswa yang diajar dengan strategi konvensional, dan (2) pengaruh interaksi antara strategi pembelajaran dan minat menjadi guru terhadap hasil belajar mata kuliah Perencanaan Pembelajaran Biologi mahasiswa jurusan Pendidikan IPA Biologi.

\section{METODE PENELITIAN}

Penelitian ini merupakan penelitian eksperimental pada mahasiswa Jurusan Pendidikan IPA Biologi, Fakultas Ilmu Tarbiyah dan Keguruan Institut Agama Islam Negeri (IAIN) Mataram pada bulan Pebruari sampai Juli 2014. Treatmenya adalah pembelajara dengan stategi pembelajaran pada kelompok mahasiswa yang memiliki minat tinggi menjadi guru dan kelompok mahasiswa yang memiliki minat rendah menjadi guru (sebagai variabel moderator). Tujuan perlakuan melihat efeknya terhadap hasil belajar mata kuliah Perencanaan Pembelajaran Biologi mahasiswa. Desain eksperimen yang digunakan adalah desain treatment by Level 2 x 2 seperti pada table 1 berikut.

\section{Tabel 1}

Desain Treatment by Level 2 x 2

\begin{tabular}{|c|c|c|}
\hline \multirow{2}{*}{$\begin{array}{c}\text { B } \\
\text { gurut menjadi }\end{array}$} & \multicolumn{2}{|c|}{$\mathrm{A}$} \\
\cline { 2 - 3 } (Stretegi Pembelajaran) \\
\hline $\mathrm{B}_{1}$ & $\mathrm{~A}_{1}$ & $\mathrm{~A}_{2}$ \\
\hline $\mathrm{B}_{2}$ & $\mathrm{~A}_{1} \mathrm{~B}_{1}$ & $\mathrm{~A}_{2} \mathrm{~B}_{1}$ \\
\hline
\end{tabular}

Keterangan:

$\mathrm{A}_{1}=$ Strategi pembelajaran kontekstual

$\mathrm{A}_{2}=$ Strategi pembelajaran konvensional

$\mathrm{B}_{1}=$ Minat tinggi menjadi guru

$\mathrm{B}_{2}=$ Minat rendah menjadi guru

Populasi target dalam dalam penelitian ini adalah mahasiswa Jurusan Pendidikan IPA Biologi semester VI yang 
menempuh mata kuliah Perencanaan Pembelajaran Biologi. Populasi terjangkau adalah mahasiswa Jurusan Pendidikan IPA Biologi semester VI tahun akademik 2013/2014 yang menempuh mata kuliah Perencanaan Pembelajaran Biologi.

Sampel diambil dengan teknik multistage random sampling, dengan tahapan sebagai berikut:

1. Merandom 80 orang mahasiswa dari 180 orang mahasiswa Jurusan Pendidikan IPA Biologi semester VI Tahun Akademik 2013/2014.

2. Menentukan 40 orang mahasiswa sebagai kelas perlakuan dan 40 orang mahasiswa sebagai kelas kontrol dengan metode random.

3. Memberikan angket minat menjadi guru pada mahasiswa kelas perlakuan dan kelas kontrol.

4. Merangking skor angket mahasiswa, kemudian menentukan $30 \%$ mahasiswa dengan skor tinggi dan 30\% mahasiswa dengan skor rendah, masing-masing berjumlah kurang lebih 12 orang. Kelompok mahasiswa dengan skor tinggi disebut memiliki minat tinggi menjadi guru, sedangkan mahasiswa dengan skor rendah disebut memiliki minat rendah menjadi guru.

Penelitian dilakukan dalam 3 tahap; Persiapan perangkat pembelajaran dan instrumen penelitian, pelaksanaan pembelajaran, dan tahap pengukuran efek perlakuan

Standarisasi instrumen dilakukan dengan menguji validitas dan reliabilitas. Uji valiliditas dilakukan untuk setiap butir pertanyaan/pernyataan dengan cara menghitung korelasi skor butir dengan skor total. Secara konseptual, suatu butir soal dikatakan valid jika skor-skor pada butir item memiliki kesusuaian atau kesejajaran arah dengan skor totalnya .

Penentuan bahwa butir valid atau tidak valid ditentukan dengan cara membandingkan nilai r-hitung dengan nilai r-tabel pada taraf signifikansi 5\%. Ketentuannya adalah; 1) jika rhitung positif dan > rtabel maka butir instrumen tersebut valid; dan 2) 
jika rhitung negatif dan rtabel maka butir instrumen tersebut tidak valid.

Penghitungan reliabilitas instrumen pada ujicoba dihitung dengan menggunakan rumus Alpha Cronbach. Persamaannya adalah sebagai berikut:

$$
r=\left(\frac{k}{k-1}\right) \frac{S D_{t-\Sigma(}^{2} S D_{i)^{\wedge} 2}}{S D_{t}^{2}}
$$

Keterangan

$$
\begin{array}{ll}
\mathrm{r} & =\text { Koefisien reliabilitas seluruh butir } \\
\mathrm{n} & =\text { Jumlah butir dalam instrumen } \\
S D_{t}^{2} & =\text { Varian skor total } \\
{ }_{\Sigma} S D_{i}^{2} & =\text { Jumlah varian butir }
\end{array}
$$

Tinggi rendahnya realibilitas ditunjukan oleh koefisien realibilitas. Koefesien reliabilitas berkisar antara 0 sampai 1 . Secara konseptual, koefisien reliabilitas 0 berarti tidak terdapat komponen yang benar dalam skor amatan. Seluruh skor amatan yang diperoleh adalah merupakan error, atau hasil dari suatu kesalahan. Koefisien reliabilitas 1 berarti skor amatan tidak mengandung error, seluruh skor yang diperoleh merupakan true score. Dalam pengukuran kependidikan, menurut Anas Sudijono, pemberian interpretasi terhadap koefisien reliabilitas tes pada umumnya menggunakan patokan; jika nilai $r$ sama dengan atau lebih besar dari 0,70, maka tes hasil belajar yang sedang diuji reliabilitasnya dinyatakan telah memiliki reliabilitas yang tinggi (reliable).

Data yang dikumpulkan ada dua macam: (1) minat mahasiswa menjadi guru dan (2) data hasil belajar mahasiswa. Data minat mahasiswa dikumpulkan dengan teknik angket menggunakan instrument angket, sedangkan data hasil belajar mahasiswa dikumpulkan dengan teknik tes menggunakan instrument soal tes.

Analisis data dilakukan untuk dua tujuan, yaitu analisis untuk pengujian persyaratan uji statistik dan analisis untuk pengujian hipotesis penelitian. Sebelum dilakukan pengujian persyaratan analisis, data dari setiap variabel dibuat analisis 
deskriptif agar didapat gambaran hasil penelitian secara umum. Data yang didapatkan dalam parameter statistik deskriptif seperti rata-rata (mean), nilai tengah (median), frekuensi terbanyak (modus), simpangan baku (standar deviation), dan penyajian data dengan grafik dan tabel. Analisis statistik inferensial dengan ANAVA dua jalur pada taraf signifikansi 5\%. Sebelum uji statistik dengan statistik inferensial terlebih dahulu dilakukan uji persyaratan uji hipotesis, yaitu uji normalitas dan uji homogenitas. Seluruh proses uji statistik menggunakan program SPSS versi 16.0 .

\section{HASIL DAN PEMBAHASAN}

\section{Hasil}

Setelah selesai pembelajaran dilakukan tes untuk mengukur hasil belajar mahasiswa pada mata kuliah Perencanaan Pembelajaran Biologi. Duabelas orang siswa mahasiswa masing-masing dengan minat tinggi dan minat rendah diambil dari kelas eksperimen dan kelas kontrol dijadikan sebagai unit analisis. Data hasil tes mahasiswa dapat dilihat pada tabel 2 .

\section{Tabel 2}

Data Hasil Belajar Mahasiswa Kelompok Perlakuan dan Kelompok Pembanding/Kontrol yang Memiliki Minat Tinggi dan Minat Rendah

\begin{tabular}{|c|c|c|c|c|}
\hline \multirow{2}{*}{} & \multicolumn{2}{|c|}{$\begin{array}{c}\text { A1 } \\
\text { (CTL) }\end{array}$} & \multicolumn{2}{c|}{$\begin{array}{c}\text { A2 } \\
\text { (Konvensional) }\end{array}$} \\
\cline { 2 - 5 } N0. & $\begin{array}{c}\text { B1 } \\
\text { (Minat } \\
\text { Tinggi) }\end{array}$ & $\begin{array}{c}\text { B2 } \\
\text { Rinat } \\
\text { Rendah) }\end{array}$ & $\begin{array}{c}\text { B1 } \\
\text { Binat Tinggi) }\end{array}$ & $\begin{array}{c}\text { (Minat } \\
\text { Rendah) }\end{array}$ \\
\hline 1 & 77 & 63 & 63 & 56 \\
\hline 2 & 56 & 84 & 84 & 63 \\
\hline 3 & 49 & 70 & 42 & 28 \\
\hline 4 & 49 & 77 & 84 & 28 \\
\hline
\end{tabular}

Tabel 2. Lanjutan

\begin{tabular}{|c|c|c|}
\hline NO. & $\begin{array}{c}\text { A1 } \\
\text { (CTL) }\end{array}$ & $\begin{array}{c}\text { A2 } \\
\text { (Konvensional) }\end{array}$ \\
\hline
\end{tabular}




\begin{tabular}{|c|c|c|c|c|}
\hline & $\begin{array}{c}\text { B1 } \\
\text { (Minat } \\
\text { Tinggi) }\end{array}$ & $\begin{array}{c}\text { B2 } \\
\text { (Minat } \\
\text { Rendah) }\end{array}$ & $\begin{array}{c}\text { B1 } \\
\text { (Minat Tinggi) }\end{array}$ & $\begin{array}{c}\text { B2 } \\
\text { (Minat } \\
\text { Rendah) }\end{array}$ \\
\hline 5 & 42 & 98 & 28 & 28 \\
\hline 6 & 70 & 77 & 56 & 49 \\
\hline 7 & 56 & 70 & 70 & 49 \\
\hline 8 & 21 & 70 & 56 & 63 \\
\hline 9 & 56 & 56 & 42 & 35 \\
\hline 10 & 70 & 84 & 56 & 28 \\
\hline 11 & 84 & 35 & 77 & 49 \\
\hline 12 & 56 & 49 & 63 & 49 \\
\hline \multicolumn{2}{|l|}{ Rata-rata $\mathrm{Bi} 57.17$} & 69.42 & 60.08 & 43.75 \\
\hline \multicolumn{2}{l}{ Rata-rata $\mathrm{A} i$} & & & 51.9 \\
\hline
\end{tabular}

\section{Tabel 3}

Perbandingan Hasil Belajar Mata Kuliah Perencanaan Pembelajaran Biologi Mahasiswa Kelompok Perlakuan dan Kelompok Pembanding/Kontrol

\begin{tabular}{|c|l|c|c|}
\hline No & \multicolumn{1}{|c|}{ Deskriptor } & $\begin{array}{c}\text { Kelas } \\
\text { eskperimen }\end{array}$ & $\begin{array}{c}\text { Kelas } \\
\text { Pembanding }\end{array}$ \\
\hline 1. & $\begin{array}{l}\text { Jumlah mahasiswa unit } \\
\text { analisis }\end{array}$ & 24 & 24 \\
\hline 2. & Nilai tertinggi & 98 & 84 \\
\hline 3. & Nilai Rendah & 21 & 28 \\
\hline 4. & Nilai rata-rata & 63,3 & 51,9 \\
\hline
\end{tabular}

Tabel 2 dan 3 menunjukkan secara deskriptif distribusi hasil belajar mahasiswa pada dua kelompok dengan minat tinggi menjadi guru dan minat rendah menjadi guru. Nilai rata-rata pada kelompok mahasiswa yang memperoleh pembelajaran dengan strategi pembelajaran kontekstual lebih tinggi dibanding pada kelompok pembanding yang mengikuti pembelajaran dengan strategi konvensional. Tabel tersebut juga menunjukkan perbedaan hasil belajar antara mahasiswa dengan minat tinggi 
dan mahasiswa dengan minat rendah di dalam kelompok kontekstual dan kelompok konvensional. Pada kelompok perlakuan, nilai rata-rata mahasiswa dengan minat tinggi menjadi guru lebih rendah dibanding nilai mahasiswa dengan minat rendah menjadi guru. Sedangkan pada kelompok konvensional, nilai rata-rata mahasiswa dengan minat tinggi lebih tinggi dibanding nilai mahasiswa dengan minat rendah menjadi guru.

Uji ANAVA terhadap data hasil belajar telah dilakukan dalam rangka melihat signifikansi perbedaan nilai rata-rata mahasiswa antara kelompok perlakuan maupun di dalam kelompok perlakuan. Sehingga ada empat tujuan uji statistik yang dilakukan, yaitu untuk mengetahui; (1) perbedaan hasil belajar mata kuliah Perencanaan Pembelajaran Biologi antara mahasiswa yang diajar dengan strategi pembelajaran kontekstual dan mahasiswa yang diajar dengan strategi konvensional, dan (2) pengaruh interaksi antara strategi pembelajaran dan minat menjadi guru terhadap hasil belajar mata kuliah Perencanaan Pembelajaran Biologi mahasiswa,

Uji statistik dilakukan dengan SPSS 16.0 pada taraf signifikansi 5\%. Hasil analisis sebagaimana pada tabel berikut.Data rata-rata aspek keterampilan proses sains kelas eksperimen dan kelas kontrol dapat ditampilkan dalam bentuk gambar diagram 1 sebagai berikut.

\section{Tabel 4}

Output Hasil SPSS Analisis Data Hasil Belajar Mahasiswa Kelompok Perlakuan dan Kelompok Pembanding yang Memiliki Minat Tinggi dan Minat Rendah Menjadi Guru

Dependent Variable:Nilai

\begin{tabular}{|l|r|r|r|r|r|}
\hline Source & $\begin{array}{c}\text { Type III Sum of } \\
\text { Squares }\end{array}$ & df & Mean Square & \multicolumn{1}{c|}{ F } & \multicolumn{1}{c|}{ Sig. } \\
\hline Corrected Model & 4053.729 & 3 & 1351.243 & 5.104 & .004 \\
Intercept & 159275.521 & 1 & 159275.521 & 601.569 & .000 \\
Strategi & 1552.688 & 1 & 1552.688 & 5.864 & .020 \\
Minat & 50.021 & 1 & 50.021 & .189 & .666 \\
Strategi * Minat & 2451.021 & 1 & 2451.021 & 9.257 & .004 \\
Error & 11649.750 & 44 & 264.767 & & \\
Total & 174979.000 & 48 & & & \\
\hline
\end{tabular}


Dependent Variable:Nilai

\begin{tabular}{|l|r|r|r|r|r|}
\hline Source & $\begin{array}{c}\text { Type III Sum of } \\
\text { Squares }\end{array}$ & df & Mean Square & \multicolumn{1}{c|}{ F } & \multicolumn{1}{c|}{ Sig. } \\
\hline Corrected Model & 4053.729 & 3 & 1351.243 & 5.104 & .004 \\
Intercept & 159275.521 & 1 & 159275.521 & 601.569 & .000 \\
Strategi & 1552.688 & 1 & 1552.688 & 5.864 & .020 \\
Minat & 50.021 & 1 & 50.021 & .189 & .666 \\
Strategi * Minat & 2451.021 & 1 & 2451.021 & 9.257 & .004 \\
Error & 11649.750 & 44 & 264.767 & & \\
Total & 174979.000 & 48 & & & \\
Corrected Total & 15703.479 & 47 & & & \\
\hline
\end{tabular}

a. R Squared $=.258$ (Adjusted $\mathrm{R}$ Squared $=.208$ )

/CRITERIA=ALPHA (0.05)

/DESIGN=Strategi Minat Strategi*Minat.

Pada tabel 4, dapat dijelaskan pengaruh strategi pembelajaran dan minat mejadi guru terhadap hasil belajar mata kuliah Perencanaan Pembelajaran Biologi mahasiswa Jurusan Pendidikan IPA Biologi FITK IAIN Mataram sebagai berikut;

1. Untuk strategi pembelajaran: nilai probabilitas uji (Sig.) $=0.020$ lebih kecil dari nilai probabilitas kriteria (alpha), yaitu 0.05. Dengan demikian HO ditolak, kesimpulannya, terdapat perbedaan hasil belajar mata kuliah Perencanaan Pembelajaran Biologi antara mahasiswa yang diajar dengan strategi pembelajaran kontekstual dan mahasiswa yang diajar dengan strategi konvensional,

2. Untuk pengaruh interaksi antara strategi pembelajaran dan minat menjadi guru; nilai probabilitas uji (Sig.) $=0.004$ lebih kecil dari nilai probabilitas kriteria (alpha), yaitu 0.05. Dengan demikian HO ditolak, kesimpulannya, terdapat pengaruh strategi pembelajaran dan minat menjadi guru terhadap hasil belajar mata kuliah Perencanaan Pembelajaran Biologi mahasiswa, 


\section{Pembahasan}

Memutuskan mengambil atau melakukan sesuatu, seseorang tak akan lepas dari dua hal, yakni karena dia memang menginginkannya atau karena terpaksa melakukannya. Ketika seseorang seorang calon mahasiswa memilih untuk menempuh pendidikan pada jurusan pendidikan/tarbiyah dia memang punya keingina/minat atau dia terpaksa memilih jurusan tersebut secara terpaksa karena tidak ada upaya lain lagi yang bisa dilakukan.

Sama halnya dengan mahasiswa yang menempuh pendidikan pada jurusan Pendidikan IPA Biologi. Secara teoritis mereka akan dididik menjadi guru yang akan mengampu pelajaran biologi di sekolah/madrasah. Tetapi persoalannya apakah semua mereka memiliki minat yang tinggi untuk menjadi guru atau sekedar keterpaksaan atau minat mereka rendah untuk menjadi guru. Minat itulah yang kemudian menjadi salah satu yang akan menentukan upaya dan keberhasilan mereka dalam pembelajaran di samping faktor-faktor yang lain.

Minat merupakan suatu rasa suka dan rasa keterikatan pada suatu hal atau aktivitas tanpa ada yang menyuruh. Minat pada dasarnya adalah penerimaan akan suatu hubungan antara diri sendiri dengan sesuatu di luar diri. Semakin kuat atau semakin dekat hubungan tersebut, semakin besar minat. Minat pada hakikatnya merupakan pernyataan kepribadian seseorang yang diwujudkan dalam kalimat terhadap sebuah jabatan atau pekerjaan. Minat terhadap pekerjaan merupakan pernyataan yang menggambarkan kepribadian dalam pekerjaan, hobi, aktivitas-aktivitas. yang berhubungan dengan rekreasi dan preferensi. Suatu minat dapat diekspresikan melalui suatu pernyataan yang menunjukkan bahwa seseorang lebih menyukai satu hal dan pada hal lainnya dapat pula dimanifestasikan melalui partisipasi dalam suatu aktivitas. Seorang yang memiliki minat terhadap subyek tertentu cenderung untuk memberikan perhatian yang lebih besar terhadap subyek tersebut.

Sebagaimana diungkapkan di atas, bahwa ada faktor lain yang menentukan upaya dan keberhasilan mahasiswa 
selain minatnya. Faktor lain tersebut seperti proses pembelajaran yang mereka alami selama menempuh pendidikan. Penelitian yang dilakukan ini telah berhasil mengungkap efek strategi pembelajaran yang dilakukan oleh dosen dan minat mahasiswa menjadi guru terhadap hasil belajar mata kuliah Perencanaan Pembelajaran Biologi pada mahsiswa jurusan Pendidikan IPA Biologi Fakultas Ilmu Tarbiyah dan Keguruan Institut Agama Islam Negeri (IAIN) Mataram.

Hasil penelitian ini menunjukkan bahwa terdapat perbedaan yang signifikan hasil belajar mata kuliah Perencanaan Pembelajaran Biologi antara mahasiswa yang diajar dengan strategi kontekstual dan mahasiswa yang diajar dengan strategi konvensional. Hal ini menandakan bahwa terdapat pengaruh yang signifikan strategi pembelajaran kontekstual terhadap hasil belajar mata kuliah perencanaan pembelajaran biologi mahasiswa. Efek ini disebabkan karena pada proses pembelajaran yang dilakukan dengan strategi kontekstual, mahasiswa dihadapkan pada objek nyata atau objek biologi pada saat melakukan kegiatan perencanaan pembelajaran. Pembelajaran yang dilakukan melibatkan dua sumber belajar sebagai acuan dalam kegiatan merencanakan pembelajaran, yaitu tujuan pembelajaran biologi yang terdapat pada standar isi (SI) yang tertuang dalam Peraturan Menteri Pendidikan dan Kebudayaan Nomor 69 tahun 2013 Tentang Kerangka Dasar dan Struktur Kurikulum Sekolah dan juga media/objek pembelajaran biologi. Sebagai contoh, ketika mahasiswa melakukan aktivitas; mengembangkan indikator, menyusun silabus, mengembangkan tahapan proses pembelajaran, mengembangkan lembar kegiatan siswa (LKS), dan menyusun instrument penilaian untuk materi atau topik tentang ekosistem, pembelajaran dilakukan di halam kampus, di mana mereka dapat melihat secara langsung ekosistem yang ada di halaman kampus dan ekosistem sawah. Pada objek nyata tersebut, mahasiswa menganalisis terhadap objek biologi di depan mereka untuk mereka pikirkan; (1) apa yang harus dipahami oleh siswa ? (2) siswa harus terampil apa? (3) bagaiamana cara pembelajaran? (4) bagaimana 
mengorganisasi siswa, dan (4) apa saja yang harus dinilai dalam pembelajaran?

Sambil menelaah objek biologi, mahasiswa juga menelaah kompetensi yang dikhendaki oleh kurikulum terhadap topik atau materi ekosistem tersebut. Dengan strategi pembelajaran seperti ini mahasiswa terbantu dalam mempertajam kemampuannya dalam menganalisis aspekaspek yang harus direncanakan dalam pembelajaran biologi yang pada akhirnya memperkuat pemahaman dan keterampilan mereka dalam merencanakan pembelajaran.

Pembelajaran dengan strategi konvensional pada mata kuliah Perencaaan Pembelajaran Biologi, mahasiswa hanya dihadapkan pada tujuan pembelajaran biologi yang terdapat pada standar isi (SI) yang tertuang dalam Peraturan Menteri Pendidikan dan Kebudayaan Nomor 69 tahun 2013 Tentang Kerangka Dasar dan Struktur Kurikulum Sekolah sebagai bahan untuk merencanakan pembelajaran. Mahasiswa diminta berpikir; (1) apa yang harus dipahami oleh siswa? (2) siswa harus terampil apa? (3) bagaiamana cara pembelajaran? (4) bagaimana mengorganisasi siswa, dan (4) apa saja yang harus dinilai dalam pembelajaran? jika melakukan pembelajaran terhadap materi ekosistem yang kompetensi dasar (KD)-nya terdapat pada standar isi yang dibagikan. Akibatnya, mahasiswa hanya membayangkan objek yang dipelajari dan mengandalkan kemampuan menganalisis KD dalam membuat perencanaan, sehingga pemahaman dan keterampilan mereka terhadap aktivitas perencanaan pembelajaran biologi tidak maksimal.

Temuan lain penelitian ini adalah terdapat pengaruh strategi pembelajaran dan minat menjadi guru terhadap hasil belajar mata kuliah Perencanaan Pembelajaran Biologi mahasiswa. Minat mahasiswa menjadi guru mengandung implikasi munculnya perasaan suka, senang, tertarik dan keterikatan yang kuat terhadap segala aktivitas yang ditimbulkan dalam proses pembelajaran. Minat menjadi guru adalah tingkat kesukaan atau ketertarikan seseorang mahasiswa terhadap pekerjaan (menjadi guru), yang dapat mendorong mereka untuk memperhatikan, menelaah dengan 
serius aktivitas dalam pembelajaran mata kuliah Perencanaan Pembelajaran Biologi. Mahasiswa melaksanakan dengan perasaan bahagia, penuh tanggung jawab dan disiplin yang tinggi tugas-tugas yang diberikan selama pembelajaran.

Di samping itu, mahasiswa yang memiliki minat yang tinggi untuk menjadi guru sangat tepat sekali proses pembelajaran yang diberkan kepada mereka yang dilakukan dengan kontekstual. Mereka memberikan porsi waktu yang lebih terkait dengan tugas-tugas yang diberikan, mengerahkan segenap tenaga dan pikiran demi tercapainya tujuan/sasaran pembelajaran yang telah direncanakan. Seorang mahasiswa yang mempunyai minat yang tinggi terhadap guru tidak akan mudah merasa lelah, capek, cepat bosan dan merasa berat terhadap tugas-tugasnya. Disini dapat dikatakan bahwa minat merupakan variabel motivasional yang dapat mengaktifkan prilaku dan respon seseorang dalam melaksanakan proksi sebagai seorang calon guru.

\section{KESIMPULAN}

Berdasarkan data hasil penelitian, analisis data, dan pembahasan, dapat disimpulkan bahwa terdapat pengaruh strategi pembelajaran dan minat menjadi guru terhadap hasil belajar mata kuliah Perencanaan Pembelajaran Biologi mahasiswa Jurusan Pendidikan IPA Biologi Fakultas Ilmu Tarbiyah Institut Agama Islam Negeri Mataram. Hal itu ditunjukan oleh temuan; (1) Terdapat perbedaan hasil belajar mata kuliah Perencanaan Pembelajaran Biologi antara mahasiswa yang diajar dengan strategi pembelajaran kontekstual dan mahasiswa yang diajar dengan strategi konvensional. (2) Terdapat pengaruh interaksi strategi pembelajaran dan minat menjadi guru terhadap hasil belajar mata kuliah Perencanaan Pembelajaran Biologi mahasiswa.

\section{DAFTAR PUSTAKA}

Fakultas Tarbiyah IAIN Mataram, 2008. Pedoman Akademik Fakultas Tarbiyah. Mataram. 
Harun Halimah, 2006. "Minat, Motivasi dan Kemahiran Mengajar Guru Pelatih". Jurnal Pendidikan. (Bangi, Selangor Darul Ehsan: Fakulti Pendidikan, Universiti Kebangsaan Malaysia, 43600 UKM)

Institut Agama Islam Negeri (IAIN) Mataram, 2012. Kurikulum IAIN Mataram Tahun 2012. Mataram: IAIN Mataram.

Undang-Undang Nomor 14 tahun 2005 tentang Guru dan Dosen

Sudijono Anas, 2006. Pengantar Evaluasi Pendidikan, (Jakarta: Raja Grafindo)

Wijaya, 2003. Statistik Parametrik: Aplikasi Program SPSS (Surabaya: Alfabeta)

Yitnosumarto Suntoyo, 1991. Percobaan: Perancangan, Analisis, dan Interpretasi. (Jakarta: Gramedia Pustaka) 